DOI https://doi.org/10.18551/rjoas.2017-11.38

\title{
ANALYSIS OF BRAND TRUST, BRAND IMAGE, AND BRAND SATISFACTION ON BRAND LOYALTY AND REPURCHASE INTENTION
}

\author{
Susetyo Hendri Rahman*, Ronny \\ STIE Perbanas Surabaya, Indonesia \\ *E-mail: hendri.rahmans@gmail.com
}

\begin{abstract}
This research aimed to examine the influence of brand trust, brand image, and brand satisfaction on brand loyalty and repurchase intention of Jawa Pos newspaper in Surabaya City. According to literature review, the hypothesis of this research stated that brand trust, brand image, and brand satisfaction influenced brand loyalty. In addition, the results of the literature review showed that brand loyalty influenced repurchase intention. The data of this research were collected by using questionnaires from respondents consisting of 210 customers of Jawa Pos newspaper in Surabaya City. Hypothesis testing technique was performed by using structure equation model (SEM) analysis with SmartPLS statistic application. The results of this research indicated that brand trust, brand image, and brand satisfaction had a positive influence on brand loyalty and brand loyalty had positive influence on repurchase intention. Specifically, this research showed that loyal customers will continuously have repurchase intention.
\end{abstract}

\section{KEY WORDS}

Image, trust, satisfaction, loyalty, brand, repurchase intention.

Nowadays, modern life is indirectly formed by the new information and communication technologies. As a key driver of this modern-era transformation, digitalization and interconnection network have created services such as mobile networks and the Internet (Kilian et al., 2012). In recent years, the internet has become a major source in searching for the information and news in which it threatens the future of newspapers around the world. In addition, the distribution of newspapers is also influenced by the availability of information from online news, websites, and social media that finally influences the number of newspaper sales (Alotaibi, 2015).

Readers, in some developed countries, through digital platform, have exceeded the number of readers compared to print media. The World Press Trends analysis estimated that at least 40 percent of global internet users used the Internet to read online newspapers (Henriksson, 2016). A survey of the World Association of Newspapers and News Publishers (WAN-IFRA), conducted in 2013, showed the variations in newspaper distribution. The survey compared newspaper distribution in 2012 and over the last five years. The results of the survey showed that there was a global downturn in newspaper distribution over the past few years of 0.9 percent; the downturn in the last five years had reached 2.2 percent (Kilman, 2013). Meanwhile, a follow-up survey, conducted by WAN-IFRA in 2015 , found that the total global newspaper revenue decreased 1.2 percent from a year earlier and decreased 4.3 percent over the past five years (Henriksson, 2016).

The statistics chart showed the heartbreaking result in the development of today's newspaper business. The problem faced was the fact that the decrease of print media revenue for ads in newspapers is slowing down or even has been falling down for years (Gigaom, 2014). Research conducted by Roy Morgan in 2016 to 22 cities in Indonesia, resulted that the Internet penetration was 54 percent and newspapers was 38 percent. At the provincial level of East Java, internet penetration was only 43 percent and newspaper was 39 percent.

The statistics chart showed the heartbreaking result in the development of today's newspaper business. The problem faced was the fact that the decrease of print media revenue for ads in newspapers is slowing down or even has been falling down for years 
(Gigaom, 2014). From the results of a survey, it was revealed that the market share of the newspaper was eroded deep enough, so that its total consumers now were only 39.3 percent. In addition, strong indications of the decrease of consumer/public interest in newspapers can also be seen from the lower number of newspaper customers; it was 15.1 percent, or went down about 2 percent compared to last year of 17.7 percent (Siswanto, 2017).

There are many dilemmas felt by newspaper publishers at the moment, such as reader aging, declining revenue and disappearing reader. In addition to this dilemma, another reason for the problems and threats in this business is internet technology that controls most of the young population. The challenges faced by the newspaper industry force them to rethink the idea about business practices, presentations and how to reach customer targets (Frooghi et al., 2015).

If consumers of print newspapers switch to reading newspapers online, newspapers are under great pressure and start thinking to earn money from their own online portals. The struggle of the newspaper industry is still very tough to keep a profit when disruptive technologies bother them; this is a long tradition of the established media industries that are not ready to be adapted and adapted to the new technology (Kueng \& Picard, 2010). Liu et al. (2011) stated that brand trust is an important mediator factor influencing consumer behavior before and after product purchase, it will result in long-term loyalty and strengthen the relationship between both parties.

Having the basis in Surabaya, Jawa Pos is one of the largest newspapers network in Indonesia that has 167 newspapers, 21 magazines/tabloids, 23 local TV stations and 20 news sites and more. Jawa Pos claims itself to be the "National News Publication from Surabaya" because on July 1, 1949 Jawa Pos was born with the name of Djawa Post in Surabaya, East Java. Based on a survey conducted by Roy Morgan at Single Source Indonesia in 2016, it was found that Jawa Pos newspaper was one of the most dominant print media in Surabaya, where its readers reached 1,622,000 people. This is of course very surprising, in the middle of the onslaught of online media which are increasingly developed at this time.

The newspaper, which was born in Surabaya, still dominates even though newspapers and other print media began to surrender competing in this business field. The image of the Jawa Pos newspaper that has been firmly rooted to people of Surabaya has given a positive support for Jawa Pos to continue being survive and leaving its competitors. Yet, is the brand image of Jawa Pos newspaper that is well known by the people of Surabaya can make a satisfaction of the people when they become the readers of Java Post newspaper? In addition, how about the repurchase intention of Jawa Pos readers when news search is now easier with the internet? Will the Jawa Pos newspaper still be accepted by the people of Surabaya or abandoned like a newspaper that had been aged because it was not strong enough to face the competition in digital era?

Online media is originally an alternative to traditional media; now it has become an irreplaceable media and begins to change our communication patterns. Therefore, brand trust and image of Jawa Pos newspaper is at stake in facing the global competition in this business field, in the middle of the loss of print media from year to year. Various ways are performed by the company to keep developing the company and create a better future; one of which is by creating customer loyalty. Based on the results of research from Nielsen in Indonesia in 2014 and Roy Morgan in 2016, that have been described above, the researcher wants to know whether there is influence between brand trust, brand image, brand satisfaction on brand loyalty and repurchase intention of Jawa Pos newspaper on the people of Surabaya in the middle of the internet development today.

\section{METHODS OF RESEARCH}

The type of the research is explanatory research; a research to explain the relationship between dependent variable and independent variable. In addition, this study is included into one-shot research, according to Sugiyono (2013), one-shot research is a research whose 
process of data collection is only performed once. In this research, the data collection was only performed once. After distributing the questionnaires to the customers of Jawa Pos newspaper in Surabaya, the data that had been collected will then be processed by the researcher.

Based on the aim and the object of the research, the population of the research was all customer of Jawa Post newspaper in Surabaya city. Moreover, the sample was part of the overall population which is chosen carefully to represent the population (Sugiyono, 2012). The criteria for determining the sample in this study are as follows: 1) being the customer of Jawa Pos newspaper, at least, has been subscribed for 6 months, 2) aged at least 19 years, 3) domiciled in Surabaya City of East Java

Hair et, al. (2010) stated that a research performing factor analysis, at least have the number of the sample member respondents as many as five times of the number of indicators under research. Actually, a better number of respondents are suggested more than ten times the number of variables. It is also supported by Sugiyono's opinion (2013) which stated that the appropriate sample size used in a study is a number of 30 to 500 samples. The number of samples used in a research is as many as $10 \times 21$ questions of the indicator $=210$ respondents. The research instrument used by the researcher was questionnaire which was developed from the modification of pre-existing measurement indicators; the questions of the questionnaire were arranged by closed question types so that the answers of the respondents were not wider than the questions.

Table 1 - Respondent's Profiles

\begin{tabular}{|c|c|c|c|}
\hline Respondent's Profiles & Category & Frequency & Percentage \\
\hline \multirow{3}{*}{ Gender } & Male & 115 & 54.8 \\
\hline & Female & 95 & 45.2 \\
\hline & Total & 210 & 100 \\
\hline \multirow{7}{*}{ Age } & $<20$ years & 6 & 2.9 \\
\hline & $21-30$ years & 46 & 21.9 \\
\hline & $31-40$ years & 49 & 23.3 \\
\hline & $41-50$ years & 63 & 30 \\
\hline & $51-60$ years & 36 & 17.1 \\
\hline & $>61$ years & 10 & 4.8 \\
\hline & Total & 210 & 100 \\
\hline \multirow{6}{*}{ Education } & High School & 30 & 14.3 \\
\hline & Diploma & 55 & 26.2 \\
\hline & Bachelor & 83 & 39.5 \\
\hline & Magister & 14 & 6.7 \\
\hline & Others & 28 & 13.3 \\
\hline & Total & 210 & 100 \\
\hline \multirow{6}{*}{ Occupation } & Entrepreneur & 44 & 21 \\
\hline & Private & 78 & 37.1 \\
\hline & Civil servant/SOE & 54 & 25.7 \\
\hline & Student & 29 & 13.8 \\
\hline & Other & 5 & 2.4 \\
\hline & Total & 210 & 100 \\
\hline \multirow{6}{*}{ Subscription Duration } & $6-12$ months & 53 & 25.2 \\
\hline & $13-24$ months & 50 & 23.8 \\
\hline & $25-36$ months & 53 & 25.2 \\
\hline & $37-48$ months & 35 & 16.7 \\
\hline & $>48$ months & 19 & 9 \\
\hline & Total & 210 & 100 \\
\hline \multirow{6}{*}{ Residence } & North Surabaya & 42 & 25 \\
\hline & East Surabaya & 42 & 25 \\
\hline & South Surabaya & 42 & 25 \\
\hline & West Surabaya & 42 & 25 \\
\hline & Central Surabaya & 42 & 25 \\
\hline & Total & 210 & 100 \\
\hline
\end{tabular}


Based on the results of data collection that had been done before, it was obtained the data on respondent's identity to complete the research information. The questionnaire was distributed in 5 administrative regions of Surabaya city: North Surabaya, East Surabaya, South Surabaya, West Surabaya and Central Surabaya; 42 questionnaires for each region. The data of the respondents being identified were based on gender, age, education, residence, occupation, and duration of Jawa Pos newspaper subscription.

Based on gender, the respondents were dominated by female by 115 people or $54.8 \%$ and the rest were male respondents by 95 persons or $45.2 \%$. For age profile, the respondents were dominated by customers aged $41-50$ years by 63 people with a percentage of $30 \%$. Respondents aged $<20$ years were 6 people or $2.9 \%$, respondents aged between 21-30 years were 46 people or $21.9 \%$, respondents aged between $31-40$ years were 49 people or $23.3 \%$, respondents aged between $51-60$ years were 36 people or $17.1 \%$ and respondents aged over 61 years were 10 people or $4.8 \%$.

In addition, the results of data collection based on the level of education, the respondents were dominated by Bachelor's degree customers by 83 people or $39.5 \%$ percentage, followed by respondents who have Diploma education by 55 people or $26.2 \%$. In addition, respondents of high-school education were 30 people or $14.3 \%$ while the respondents who educated Masters as many as 14 people or $6.7 \%$ and the rest were respondents whose education were other than high school, Bachelor, Diploma and Master by 28 people or $13.3 \%$. For the data of respondents' occupation, the respondents were dominated by private employees by 78 people or $37.1 \%$, the respondents who worked as civil servants/SOEs were 54 people or $25.7 \%$, the respondents of entrepreneur were 44 people or $21 \%$ and the respondents who work other than entrepreneur, private and civil servants/SOEs as were 29 people or $13.8 \%$ and the respondents of students were 5 people or $2.4 \%$.

Based on the subscription duration, the respondents were dominated by customers who had subscribed to Jawa Pos newspaper for 6-12 months and 25-36 months by 53 people or $25.2 \%$, the respondents who had subscribed for $13-24$ months were 50 people or $23.8 \%$, the respondents who had subscribed for $37-48$ months were 35 people or $16.7 \%$ and the respondents who had subscribed for more than 48 months were 19 people or $9 \%$. According to the location of residence, the customers live in west Surabaya, central Surabaya, south Surabaya, east Surabaya and north Surabaya, each were 42 people with the percentage of $20 \%$.

\section{RESULTS AND DISCUSSION}

Testing Results of Convergent Validity. The first evaluation of the measurement model was convergent validity. To see the testing results of convergent validity, it was performed by looking at the results of the measurement instruments (questionnaires) in the output of combined and cross loadings. The assessment of the convergent validity itself was based on the feasibility of the model whether the model was valid and met the convergent validity. In addition, the feasibility of a model could also be seen from the value of t-statistics in which the t-statistics must be greater than t-count of 1.96 at the significance level of 0.05 . In addition, the testing result of convergent validity from the measurement instrument (questionnaire) in this research could be seen in the following table:

Table 2 - Testing Results of Convergent Validity of Brand Trust

\begin{tabular}{|c|c|c|c|}
\hline Questions & Original Sample (O) & Standard Error (STERR) & T-Statistics $(|\mathrm{O} / \mathrm{STERR}|)$ \\
\hline BT1 <- Trust & 0.579 & 0.103 & 5.595 \\
\hline BT2 <- Trust & 0.717 & 0.068 & 10.505 \\
\hline BT3 <- Trust & 0.422 & 0.165 & 2.560 \\
\hline BT4 <- Trust & 0.658 & 0.122 & 5.393 \\
\hline BT5 <- Trust & 0.667 & 0.086 & 7.762 \\
\hline
\end{tabular}


Table 3 - Testing Results of Convergent Validity of Brand Image

\begin{tabular}{|c|c|c|c|}
\hline Questions & Original Sample (O) & Standard Error (STERR) & T-Statistics (|O/STERR|) \\
\hline BI1 <- Image & 0.727 & 0.135 & 5.371 \\
\hline BI2 <- Image & 0.787 & 0.082 & 9.547 \\
\hline BI3 <- Image & 0.749 & 0.159 & 4.713 \\
\hline
\end{tabular}

Table 4 - Testing Results of Convergent Validity of Brand Satisfaction

\begin{tabular}{|c|c|c|c|}
\hline Questions & Original Sample (O) & Standard Error (STERR) & T-Statistics (|O/STERR|) \\
\hline BS1<- Satisfaction & 0.746 & 0.135 & 5.519 \\
\hline BS2<- Satisfaction & 0.746 & 0.135 & 5.519 \\
\hline BS3<- Satisfaction & 0.443 & 0.121 & 3.655 \\
\hline BS4<- Satisfaction & 0.433 & 0.165 & 2.629 \\
\hline BS5<- Satisfaction & 0.790 & 0.073 & 10.793 \\
\hline
\end{tabular}

Table 5 - Testing Result of Convergent Validity of Brand Loyalty

\begin{tabular}{|c|c|c|c|}
\hline Questions & Original Sample (O) & Standard Error (STERR) & T-Statistics (|O/STERR|) \\
\hline BL1 <- Loyalty & 0.599 & 0.106 & 5.674 \\
\hline BL2 <- Loyalty & 0.714 & 0.051 & 13.944 \\
\hline BL3 <- Loyalty & 0.475 & 0.098 & 4.836 \\
\hline BL4 <- Loyalty & 0.652 & 0.076 & 8.605 \\
\hline BL5 <- Loyalty & 0.727 & 0.071 & 10.243 \\
\hline
\end{tabular}

Table 6 - Testing Results of Convergent Validity of Repurchase Intention

\begin{tabular}{|c|c|c|c|}
\hline Questions & Original Sample (O) & Standard Error (STERR) & T-Statistics (|O/STERR|) \\
\hline $\mathrm{RI} 1<-$ Intention & 0.793 & 0.052 & 15.334 \\
\hline $\mathrm{RI} 2<-$ Intention & 0.792 & 0.052 & 15.177 \\
\hline $\mathrm{R} / 3<-$ Intention & 0.652 & 0.091 & 7.166 \\
\hline
\end{tabular}

The five indicators of brand trust variable were valid and statistically significant in measuring brand trust variable. It could be seen from the loading value $(\lambda)$ of all indicators; they were more than 0.50 with the T-statistics more than 1.96. Meanwhile, the three indicators of the brand image variable were valid and statistically significant in measuring the brand image variable. It could be seen from the loading value $(\lambda)$ of all its indicators; they were more than 0.50 with T-statistic more than 1.96 . For the convergent validity, it could be concluded that the five indicators of the brand satisfaction variable were valid and statistically significant in measuring the brand satisfaction variable. It could be seen from the loading value $(\lambda)$ of all its indicators; they were more than 0.50 with T-statistic more than 1.96. In addition to the testing conclusion of convergent validity of 5 indicators, it could be concluded that the five indicators of brand loyalty variables were valid and statistically significant in measuring brand loyalty variable. It could be seen from the loading value $(\lambda)$ of all its indicators; they were more than 0.50 with T-statistic more than 1.96.

In addition, from the presented test results, the conclusion could be drawn that the three indicators of repurchase intention variable were valid and statistically significant in measuring the repurchase intention variable. It could be seen from the loading value $(\lambda)$ of all its indicators; they were more than 0.50 with T-statistic more than 1.96.

Based on the value of cross loading, it could be seen that all the indicators that make up each variable in this research (the value in bold) had met the discriminant validity because it had the largest value of cross loading; for the variables it formed and not for other variables. Thus, all indicators in each variable of this research had met the discriminant validity.

The Influence of Brand Trust on Brand Loyalty. The influence of brand trust on brand loyalty of Jawa Pos newspaper to the people of Surabaya was tested by using SmartPLS. From the result of data analysis, it was known that path coefficient value at brand trust variable was equal to 0.180 with $\mathrm{t}$-statistic value of 2.124 . Due to the result of t-statistic value more than 1.96, $\mathrm{H} 0$ was rejected and $\mathrm{H} 1$ was accepted. 
According to the results of this research, it could be seen that the brand trust has a significant positive influence on brand loyalty, so this hypothesis could be accepted. The results of this research was in line with the research conducted by Upamannyu and Mathur (2013), they showed that brand trust had a positive influence on brand loyalty.

In addition, research conducted by Richard Chinomona (2016), Abdullah Alhaddad (2015), Riyan Hadi Widjaja (2015), Kha, Ching Wee, et al. (2012) also supported and strengthened the results of the research conducted by Upamannyu and Mathur (2013), in which proved that brand trust influenced positively to brand loyalty.

Table 7 - Discriminant Validity Test

\begin{tabular}{|c|c|c|c|c|c|}
\hline Variable & Image & Intention & Trust & Satisfaction & Loyalty \\
\hline $\mathrm{BI} 1$ & 0.727 & 0.272 & 0.208 & 0.063 & 0.180 \\
\hline $\mathrm{BI} 2$ & 0.787 & 0.187 & 0.232 & 0.147 & 0.219 \\
\hline $\mathrm{BI3}$ & 0.749 & 0.162 & 0.195 & 0.177 & 0.164 \\
\hline BT1 & 0.076 & 0.030 & 0.579 & 0.172 & 0.144 \\
\hline BT2 & 0.370 & 0.198 & 0.717 & 0.262 & 0.222 \\
\hline BT3 & 0.062 & 0.026 & 0.422 & 0.039 & 0.104 \\
\hline BT4 & 0.097 & 0.228 & 0.658 & 0.100 & 0.205 \\
\hline BT5 & 0.144 & 0.180 & 0.667 & 0.143 & 0.230 \\
\hline BS1 & 0.112 & 0.093 & 0.141 & 0.746 & 0.171 \\
\hline BS1 & 0.112 & 0.093 & 0.141 & 0.746 & 0.171 \\
\hline BS3 & 0.126 & 0.123 & 0.069 & 0.443 & 0.180 \\
\hline BS4 & 0.100 & 0.003 & 0.061 & 0.433 & -0.006 \\
\hline BS5 & 0.127 & 0.233 & 0.269 & 0.790 & 0.425 \\
\hline $\mathrm{RI} 1$ & 0.214 & 0.793 & 0.259 & 0.117 & 0.391 \\
\hline $\mathrm{R} / 2$ & 0.192 & 0.792 & 0.143 & 0.227 & 0.334 \\
\hline RI3 & 0.218 & 0.652 & 0.099 & 0.165 & 0.231 \\
\hline BL1 & 0.094 & 0.280 & 0.103 & 0.420 & 0.599 \\
\hline BL2 & 0.125 & 0.297 & 0.229 & 0.348 & 0.714 \\
\hline BL3 & 0.107 & 0.157 & 0.259 & 0.109 & 0.475 \\
\hline $\mathrm{BL} 4$ & 0.214 & 0.227 & 0.103 & 0.147 & 0.652 \\
\hline BL5 & 0.264 & 0.382 & 0.284 & 0.156 & 0.727 \\
\hline $\mathrm{BI} 1$ & 0.727 & 0.272 & 0.208 & 0.063 & 0.180 \\
\hline $\mathrm{Bl} 2$ & 0.787 & 0.187 & 0.232 & 0.147 & 0.219 \\
\hline $\mathrm{BI3}$ & 0.749 & 0.162 & 0.195 & 0.177 & 0.164 \\
\hline BT1 & 0.076 & 0.030 & 0.579 & 0.172 & 0.144 \\
\hline BT2 & 0.370 & 0.198 & 0.717 & 0.262 & 0.222 \\
\hline BT3 & 0.062 & 0.026 & 0.422 & 0.039 & 0.104 \\
\hline BT4 & 0.097 & 0.228 & 0.658 & 0.100 & 0.205 \\
\hline BT5 & 0.144 & 0.180 & 0.667 & 0.143 & 0.230 \\
\hline BS1 & 0.112 & 0.093 & 0.141 & 0.746 & 0.171 \\
\hline BS2 & 0.112 & 0.093 & 0.141 & 0.746 & 0.171 \\
\hline BS3 & 0.126 & 0.123 & 0.069 & 0.443 & 0.180 \\
\hline BS4 & 0.100 & 0.003 & 0.061 & 0.433 & -0.006 \\
\hline BS5 & 0.127 & 0.233 & 0.269 & 0.790 & 0.425 \\
\hline RI1 & 0.214 & 0.793 & 0.259 & 0.117 & 0.391 \\
\hline RI2 & 0.192 & 0.792 & 0.143 & 0.227 & 0.334 \\
\hline $\mathrm{RI3}$ & 0.218 & 0.652 & 0.099 & 0.165 & 0.231 \\
\hline $\mathrm{BL1}$ & 0.094 & 0.280 & 0.103 & 0.420 & 0.599 \\
\hline BL2 & 0.125 & 0.297 & 0.229 & 0.348 & 0.714 \\
\hline BL3 & 0.107 & 0.157 & 0.259 & 0.109 & 0.475 \\
\hline $\mathrm{BL} 4$ & 0.214 & 0.227 & 0.103 & 0.147 & 0.652 \\
\hline BL5 & 0.264 & 0.382 & 0.284 & 0.156 & 0.727 \\
\hline
\end{tabular}

Table 8 - Test the Influence of Brand Trust on Brand Loyalty

\begin{tabular}{|c|c|c|c|}
\hline Variable & Original Sample (O) & Standard Error (STERR) & T-Statistics (|O/STERR|) \\
\hline Brand Trust -> Brand Loyalty & 0.180 & 0.085 & 2.124 \\
\hline
\end{tabular}

The Influence of Brand Image on Brand Loyalty. The influence of brand image on brand loyalty of Jawa Pos newspaper to the people of society was tested by using 
SmartPLS. The value of path coefficient on the brand image variable was 0.146 with the tstatistic value of 2.173. Due to the result of t-statistic value more than 1.96 then $\mathrm{H} 0$ was rejected and $\mathrm{H} 1$ was accepted. From these results, it could be concluded that brand image had a significant positive influence on brand loyalty; so this hypothesis could be accepted. According to the results of this research, it could be seen that brand image had a significant positive influence on brand loyalty, so this hypothesis could be accepted. The results of this research was in line with the result of the research conducted by Upamannyu and Mathur (2013), they indicated that brand image had a positive influence on brand loyalty.

In addition, a research conducted by Habib \& Aslam (2014) and Alhaddad (2015) also supported and strengthened the results of research conducted by Upamannyu and Mathur (2013) which proved that brand image had a positive influence on brand loyalty.

Table 9 - Test of Brand Image Effect on Brand Loyalty

\begin{tabular}{|c|c|c|c|}
\hline Variable & Original Sample (O) & Standard Error (STERR) & T-Statistics (|O/STERR|) \\
\hline Brand Trust $\rightarrow$ Brand Loyalty & 0.146 & 0.067 & 2.173 \\
\hline
\end{tabular}

The Influence of Brand Satisfaction on Brand Loyalty. The influence of brand satisfaction on brand loyalty of Jawa Pos newspaper to the people of Surabaya was tested by using SmartPLS. The value of path coefficient on brand satisfaction variable was 0.321 with a t-statistic value of 4.619. Due to the result of t-statistic value more than 1.96 , then $\mathrm{HO}$ was rejected and $\mathrm{H} 1$ was accepted. From these results, it could be concluded that brand satisfaction had a significant positive influence on brand loyalty, so this hypothesis could be accepted. The result of this research was in line the result of the research conducted by Marist et al. (2014), they indicated that brand satisfaction had a positive influence on brand loyalty. In addition, research conducted by Widjaja (2015) also supported and strengthened the results of this research, in which it proved that brand satisfaction positively influenced brand loyalty.

Table 10 - The Test of the Influence of Brand Satisfaction on Brand Loyalty

\begin{tabular}{|c|c|c|c|}
\hline Variable & Original Sample (O) & Standard Error (STERR) & T-Statistics (|O/STERR|) \\
\hline Brand Satisfaction -> Brand Loyalty & 0.321 & 0.070 & 4.619 \\
\hline
\end{tabular}

Brand Satisfaction on Brand Trust of Jawa Pos Newspaper to the People of Surabaya. The influence of brand satisfaction on brand trust of Jawa Pos newspaper to the people of Surabaya was tested by using SmartPLS. The value of path coefficient on brand satisfaction variable was 0.259 with a t-statistic value of 4.208 . Due to the result of t-statistic value more than 1.96, then $\mathrm{H} 0$ was rejected and $\mathrm{H} 1$ was accepted. From these results, it could be concluded that brand satisfaction had a significant positive influence on brand loyalty, so this hypothesis could be accepted. The results of this research was in line with the result of the research conducted by Marist et al. (2014), they showed that brand satisfaction had a positive influence on brand loyalty.

Table 11 - The Test of the Influence of Brand Satisfaction on Brand Trust

\begin{tabular}{|c|c|c|c|}
\hline Variable & Original Sample (O) & Standard Error (STERR) & T-Statistics (|O/STERR|) \\
\hline Brand Satisfaction -> Brand Trust & 0.259 & 0.061 & 4.208 \\
\hline
\end{tabular}

Table 12 - The Test of Influence of Brand Loyalty on Repurchase Intention

\begin{tabular}{|c|c|c|c|}
\hline Variable & Original Sample (O) & Standard Error (STERR) & T-Statistics (|O/STERR|) \\
\hline $\begin{array}{c}\text { Brand Loyalty -> Repurchase } \\
\text { Intention }\end{array}$ & 0.438 & 0.058 & 7.539 \\
\hline
\end{tabular}

Brand Loyalty on Repurchase Intention. The influence of brand loyalty to the repurchase intention of Jawa Pos newspaper to the people of Surabaya was tested by using SmartPLS. The value of path coefficient on brand loyalty variable was 0,438 with t-statistic 
value equal to 7,539 . Due to the result of t-statistic value more than 1.96 , then $H_{0}$ was rejected and $\mathrm{H} 1$ was accepted.

From these results, it could be concluded that brand loyalty had a significant positive influence on repurchase intention, so this hypothesis could be accepted. The results of this research was in line with the result of the research conducted by Habib and Aslam (2014), they indicated that brand loyalty had a positive influence on repurchase intention. In addition, research conducted by Feng and Yanru (2013) and Kha et al (2012) also supported and strengthened the results of the research conducted by S Habib and Aslam (2014), in which proved that brand loyalty had a positive influence on repurchase intention.

\section{CONCLUSION AND SUGGESTIONS}

Based on the results of the research and discussion that had been described, it could be concluded that brand trust, brand image, and brand satisfaction had a positive influence on brand loyalty; brand loyalty have a positive influence on repurchase intention. Based on these result, it is suggested that the next researcher develop this research by examining other factors that could influence customer's loyalty and repurchase intention of the newspapers. Moreover, the addition of the number of samples is also necessary to be taken into account considering the large number of Jawa Pos newspaper customers in Surabaya City. The research area is also necessarily to get more attention so that the research can be conducted to the smallest scope in Surabaya City; for instance, the scope of the village, with the aim that the results obtained will represent all customers of Surabaya City. The future researcher can further consider other methods of examining customer's loyalty, for example, by using in-depth interviews with the customers, so that the information can be more varied rather than using the questionnaire as the research instrument; in which the answers are available in the sheet.

\section{REFERENCES}

1. Alhaddad, A. (2015). A structural model of the relationships between brand image, brand trust and brand loyalty. International Journal of Management Research and Reviews, 5(3), 137.

2. Alotaibi, S. (2015). How saudis who use the internet see the future of print newspapers in the digital age. Arkansas State University.

3. Feng, J., \& Yanru, H. (2013). Study On The Relationships Among Customer Satisfaction, Brand Loyalty And Repurchase Intention. Journal Of Theoretical \& Applied Information Technology, 49(1).

4. Frooghi, R., Waseem, S. N., Afshan, S., \& Shah, Z. (2015). Effect of offline parent brand dimension on online trust, satisfaction and loyalty: In Context of Newspaper Industry. Journal of Management Sciences, 2(2), 223-254.

5. Gigaom. (2014). Everything you need to know about the future of newspapers is in these two charts. Newstex Trade \& Industry Blogs. Chatham: Newstex.

6. Habib, S., \& Aslam, S. (2014). Influence of Brand Loyalty on Consumer Repurchase Intentions of Coca-Cola. European Journal of Business and Management, 6(14), 168174.

7. Hair, Joseph F, Jr., William C. Black., Barry J. Babin., Rolph E. Anderson., and Ronald L. Tatham,. 2010, Multivariate Data Analysis 7th Edition, Pearson Prentice Hall.

8. Henriksson, T., 2016. WAN-IFRA. Tersedia: http://www.wanifra.org/articles/2016/06/12/full-highlights-of-world-press-trends-2016-survey [Diakses Tanggal 5 Februari 2017]

9. Kha, C. W., Goh, E. K., Goh, W., Chin, J. K. P., \& Shim, P. P. (2011). Modelling repurchase intention of Proton automobile using SEM technique, Doctoral dissertation, UTAR. 
10. Kilian, T., Hennigs, N., \& Langner, S. (2012). Do Millennials read books or blogs? Introducing a media usage typology of the internet generation. Journal of Consumer Marketing, 29(2), 114-124.

11. Kilman, L. 2013. WAN-IFRA. Tersedia: http://www.wan-ifra.org/pressreleases/2013/06/02/world-press-trends-Increasing-audience-engagement-is-future-fornews-media [Diakses Tanggal 5 Februari 2017]

12. Kueng, L., \& Picard, R., 2010. Organizational origins of the media industries' troubled response to new technology. In IX World Media Economics and Management Conference, Bogota, Columbia.

13. Liu, C. T., Guo, Y. M., \& Lee, C. H. (2011). The effects of relationship quality and switching barriers on customer loyalty. International Journal of Information Management, 31(1), 71-79.

14. Marist, A. I., Yulianti, L. N., \& Najib, M. (2014). The Role of Event in Building Brand Satisfaction, Trust and Loyalty of Isotonic Drink. International Journal of Marketing Studies, 6(6), 57.

15. Siswanto, S. (2017). Efek Perkembangan Teknologi Informasi Komunikasi (Ict) Pada Media Cetak Di Era Konvergensi. Prosisko: Jurnal Pengembangan Riset dan Observasi Sistem Komputer, 4(1).

16. Sugiyono. 2012. Metode Penelitian Kuantitatif Kualitatif dan R\&D. Bandung: Alfabeta.

17. Sugiyono. 2013. Metode Penelitian Pendidikan Pendekatan Kuantitatif, Kualitatif, dan R\&D. Bandung: Alfabeta

18. Upamannyu, N. K., \& Mathur, G. (2013). Effect of brand trust, brand affect and brand image on customer brand loyalty and consumer brand extension attitude in FMCG sector. In PRIMA (Vol. 3, No. 2, p. 1). Publishing India Group.

19. Widjaja, R. H., 2015. Studi Explanatory Brand Experience, Brand satisfaction dan Brand Trust Terhadap Brand Loyalty Pada Global Automobile Brand Jenis MPV di Surabaya. Undergraduate thesis, UBAYA. 